\title{
Studies on the Adsorption Behavior of Eu (III) on Synthesized Graphene Oxide
}

\author{
N. A. Mohamed , F.H. El-Sweify ${ }^{\text {b, }}$, D.A. Abd El-Monem ${ }^{a}$, H.E. Ramadan ${ }^{\mathrm{c}}$ and W.S. Hegazy \\ ${ }^{a}$ Chemistry Department, Faculty of Women for Arts, Science and Education, Ain-Shams University, \\ Cairo, Egypt. \\ ${ }^{b}$ Nuclear Chemistry Department, Hot Labs. Center, Atomic Energy Authority, P.O. No. 13759, Cairo \\ Egypt \\ ${ }^{\mathrm{c}}$ Radioisotope and Generator department, Hot Labs. Center, Atomic Energy Authority, P.O. No. 13759, \\ Cairo, Egypt.
}

\begin{abstract}
Graphene oxide (GO) Samples are locally synthesized for use in sorption and radionuclides removal studies of ${ }^{152+154} \mathrm{Eu}$ (III). The samples were characterized by FT-IR, X-ray diffraction (XRD) and electron scanning microscopy (SEM). These samples are used to study the adsorption of some inorganic acids $\mathrm{HCl}, \mathrm{HNO}_{3}, \mathrm{H}_{2} \mathrm{SO}_{4}$ and $\mathrm{H}_{3} \mathrm{PO}_{4}$ as well as organic acetic, oxalic, citric, tartaric and EDTA acids from dilute solutions at low concentrations. The adsorption behavior of ${ }^{152+154} \mathrm{Eu}$ (III) was studied under static conditions. Effects of: $\mathrm{pH}$ solution, contact time, particle size, concentration of metal ion and adsorption kinetics temperature are intensively studied in this study.

Thermodynamic parameters such as Gibbs free energy changes $\left(\Delta \mathrm{G}^{\circ}\right)$, enthalpy $\left(\Delta \mathrm{H}^{\circ}\right)$ and entropy $\left(\Delta \mathrm{S}^{\circ}\right)$ are estimated. The adsorption, isotherms and kinetics process was analyzed using various models. In the case of Eu (III), adsorption is found to obey Langmuir isotherm stronger than Freundlich isotherm and the pseudo-second order kinetics mathematics the data for adsorption.
\end{abstract}

Keywords: Graphene oxide, Radionuclides, Entropy, Enthalpy, Pseudo-second order.

\section{INTRODUCTION}

The graphene oxides (GO) were the most appropriate substrate for radionuclides and heavy metal ions treatment since they had an excellent sorption potential [1]. In recent times GO, the use

*Corresponding author: F.H. El-Sweify, Nuclear Chemistry Department, Hot Labs. Center, Atomic Energy Authority, P.O. No. 13759, Cairo, Egypt.

E-mail: felsweify@hotmail.com 
of an efficient adsorbent to eliminate radionuclides from wastewater has attracted considerable attention [2]. Removal of radionuclides from aqueous waste solutions of large volume and their immobilization in solid phase of limited volume result in a sharp reduction of the amount of radioactive liquid waste and environmental remediation. Particularly long lived radionuclides are very harmful to human health. For instance, in the case of Japan earthquake accident (2011) some abundant long lived dangerous nuclides such as ${ }^{90} \mathrm{Sr},{ }^{137} \mathrm{Cs},{ }^{235} \mathrm{U}$, and ${ }^{129} \mathrm{I}$ were released in to the environment [3]. Radionuclides of this kind can pose a long-term risk to human health and biodiversity [4].

While the exact structure of GO is difficult to determine, it is clear that ketones, epoxides, alcohols and carboxylic groups disturb the previously aromatic lattice of graphene [5]. The presence of abundant oxygenated functional groups on GO cases makes the material very hydrophilic, making it a good candidate for use in applications for polymer composites, energyrelated materials, sensors, biomedical and "paper-like" materials applications [6] and thus, endows it with a high propensity to absorb water and swell in aqueous conditions, greatly degrading its targeted environment performance [7].

GO implementations have had many benefits over using the ion exchangers, e.g. natural minerals. First, GO is more stable than other natural minerals that undergoing chemical/physical changes [8], whereas the properties of synthetic materials can be regulated and adapted to different environmental requirements. Secondly, actinide sorption to GO reaches balance faster than its sorption to natural minerals, within 10 minutes to 1 hour. Lastly, GO has capacity 10 to 100 times greater sorption ability than natural minerals [9].

The purpose of the present research is to study the factors: influence the adsorption of some hazardous radioactive isotopes of nuclear significance from various aqueous solutions and the kinetics of the adsorption.

\section{EXPERIMENTAL}

Chemicals: All used chemicals (organic and inorganic) are of analytical grade. The chemicals used to synthesize $\mathrm{GO}$, i.e. $\mathrm{KMnO}_{4}$, flake graphite and $\mathrm{NaNO}_{3}$ are purchased from Merck (Germany), EDTA Na ${ }^{+}$salt, Hydrochloric acid and Sulphuric acid are a product of Adwic, Egypt. $\mathrm{H}_{3} \mathrm{PO}_{4}$ is a product of Pekings reagent standard (England). 
Radioisotopes: Using $\gamma$-ray spectrometry, the radioisotope ${ }^{152+154} \mathrm{Eu}$ (III) is used to trace the respective components. In the Egyptian second research reactor ET-RR-2, at Inshas, this isotope is prepared by irradiate the corresponding salts. Stock solutions of this element are prepared in solutions of $6 \mathrm{M} \mathrm{HCl}$. The following nuclear reactions read as follows:

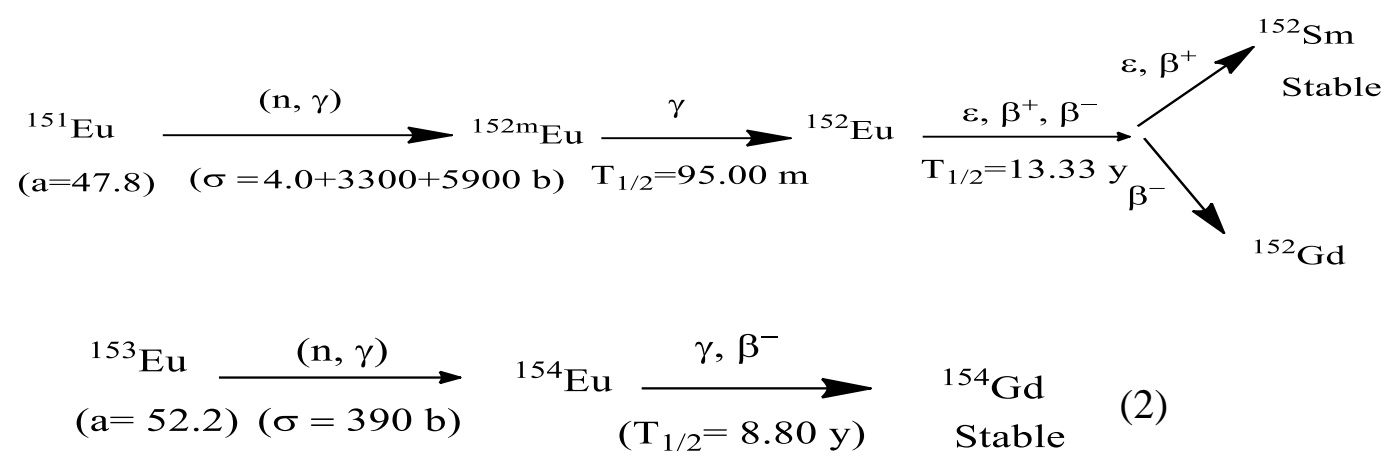

Where (a) is the isotopic abundance $(\%),(\sigma)$ is the cross section and $\mathrm{T}_{1 / 2}$ is the half -life radioactive isotopes.

Radioisotope is tested using $\gamma$ - ray spectrometry at their characteristic $\gamma$ energies using a 8192 multichannel analyzer with hyper pure Ge-detector with a resolution of $1.8 \mathrm{keV}$ at $1332.5 \mathrm{keV}$ and $30 \%$ efficiency compared to a $\mathrm{NaI}(\mathrm{Tl})$ detector.

\section{PROCEDURE}

Preparation of graphene oxide: The GO sample is synthesized by the updated process according to Hummers [10] and [11] by oxidation of graphite.

Characterization: the synthesized GO is analyzed using a Bomem Michelson FT-IR spectrometer. The morphology and grain size of GO samples are identified using Jeol scanning electron microscope (SEM) Japan. X-ray diffraction analysis is carried out using a Philips X-ray diffractometer, with a nickel filter and a $\mathrm{Cu} \mathrm{K}_{\alpha}$-X-radiation tube.

Sorption under static conditions: For GO adsorption of ${ }^{152+154} \mathrm{Eu}$ (III) samples, the distribution coefficient and percentage uptake values were calculated in batch experiments. Aliquots of 5.0 $\mathrm{mL}$ of a solution containing the desired radioactive isotopes are equal to $0.05 \mathrm{~g}$ GO. After the required balance time, all aqueous solution aliquots are collected and radiometrically valuated in accordance with equations 3 and 4 below to determine the distribution coefficient, $\mathrm{Kd}$ $\left(\mathrm{mL} \cdot \mathrm{g}^{-1}\right)$ and the uptake rate. 


$$
\begin{aligned}
& \mathrm{K}_{\mathrm{d}}=\frac{\mathrm{Ao}-\mathrm{A}}{\mathrm{A}} \times \frac{\mathrm{V}}{\mathrm{M}} \\
& \% \text { Uptake }=\frac{\text { Ao }-\mathrm{A}}{\text { Ao }} \times 100
\end{aligned}
$$

Where, before and after interaction with the synthesized graphene oxide for the time needed, $A_{o}$ and $\mathrm{A}$ are the areas under the $\gamma$ - ray peaks of the given radionuclides, respectively. $\mathrm{V}$ implies the aqueous phase volume $(\mathrm{mL})$ and the graphene oxide weight $(\mathrm{g})$ is metered by $\mathrm{M}$.

\section{RESULTS AND DISCUSSION}

Fig.(1) A, B and C represents the obtained data for characterization of the synthesized GO using SEM, XRD and FT-IR techniques, respectively.

Scan electron microscopy: The synthesized GO morphology is investigated using image of SEM. The SEM images Fig. 1A indicated that the surface accumulated GO is randomly smooth and has an edge part which indicated that GO has been fully exfoliated as there is a crimp in the old state of oxidation [13].

X-ray diffraction data: XRD analysis is one of the simplest techniques used to describe GO structurally as shown in Fig. 1B. The strong characteristic $2 \theta$ peak for GO is attributed to the interlayer distance $0.811 \mathrm{~nm}$ appears at $10.89^{\circ}$ [14]. The broad interlayer spacing of GO occurred during the oxidation process may be due to the presence of different oxygen-containing functional groups on the basal planes of GO layers [15].

FT-IR spectrum: The FT-IR spectrum of the synthesized GO sample presented in Fig.1C indicate the presence of specific functional oxygen-based groups, such as ketonic groups, hydroxyl, carboxyl, epoxide, $\mathrm{Sp}^{2}$ hybridized $\mathrm{C}=\mathrm{C}$ and $\mathrm{C}=\mathrm{O}$ containing chemical groups. The broad and intense peak at $3565-3394 \mathrm{~cm}^{-1}$ denotes an $\mathrm{O}-\mathrm{H}$ stretching vibration with inter molecular bonding of hydrogen. The GO peaks at $1714,1612,1391$ and $1039 \mathrm{~cm}^{-1}$ refer to the carbonyl $\mathrm{C}=\mathrm{O}$, aromatic $\mathrm{C}=\mathrm{C}$, carboxyl $\mathrm{O}=\mathrm{C}-\mathrm{O}$ and alcoxy $\mathrm{C}-\mathrm{O}-\mathrm{C}$ stretching vibrational modes, respectively [16]. The peak located at $1165 \mathrm{~cm}^{-1}$ represents a $\mathrm{C}-\mathrm{OH}$ stretching vibration and the bands at $669 \mathrm{~cm}^{-1}$ correspond to $\mathrm{C}-\mathrm{H}$ out-of-plane bending vibration, while the peak at $870 \mathrm{~cm}^{-1}$ may due to a $\mathrm{C}-\mathrm{H}$ bending in-plane. These hydrophilic oxygen-containing functional groups give GO with strong 
water dispersibility [17]. Therefore, the FTIR spectrum reveals that GO comprises a broad variety of oxygen functional groups on its surfaces and defect regions.
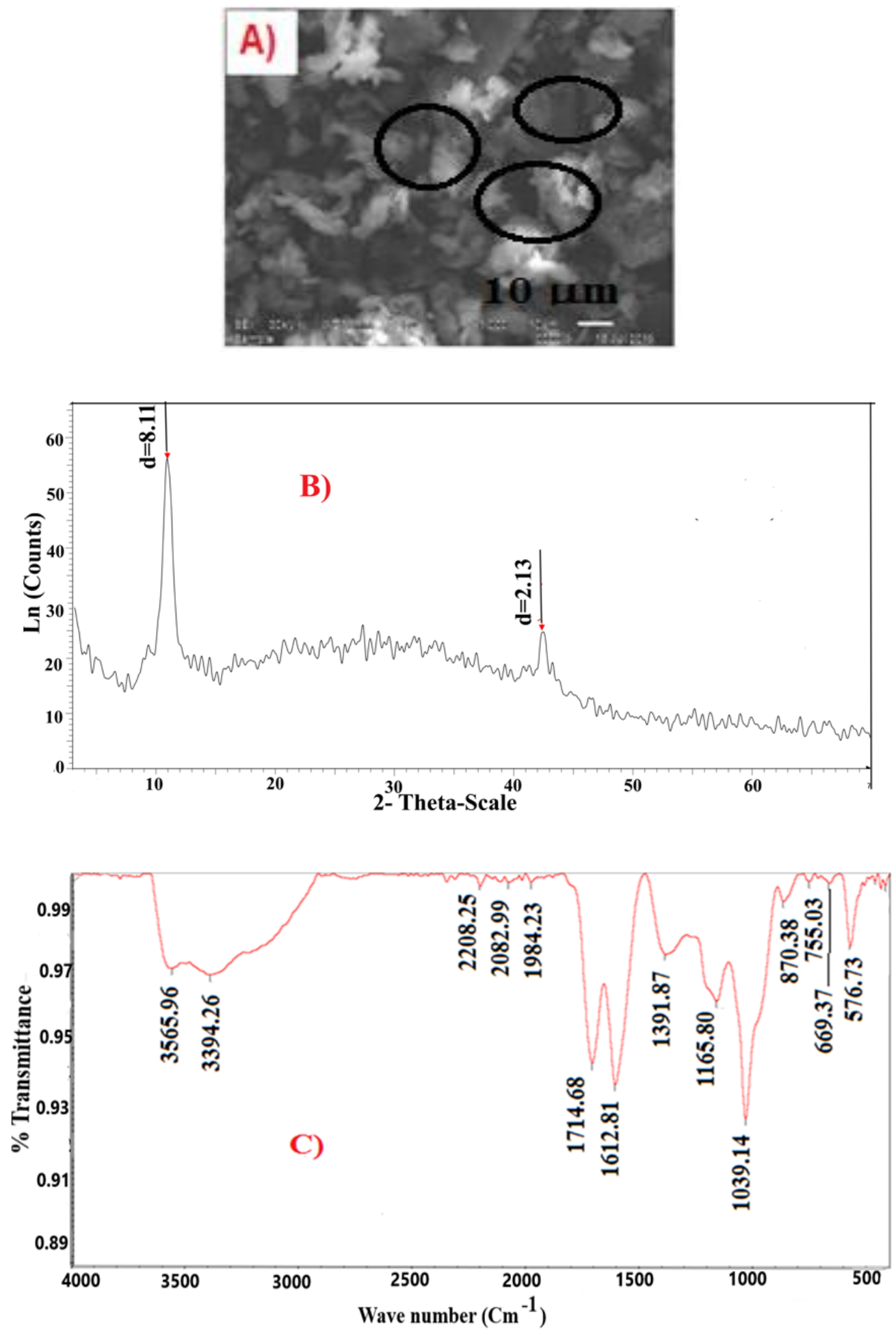
Fig. (1): Characterization of the synthesized GO sample. A) SEM images B) X- Ray diffraction data and C) FT-IR spectra.

1- Adsorption behavior: The adsorption behavior of some inorganic and some organic acids on GO from aqueous solutions having different acid concentrations is studied.

a - Inorganic acids, $\mathrm{HCl}, \mathrm{HNO}_{3}, \mathrm{H}_{2} \mathrm{SO}_{4}$ and $\mathrm{H}_{3} \mathrm{PO}_{4}$

Figure (2) represent the influence of acids concentration on the percentage uptake values of $\mathrm{HCl}, \mathrm{HNO}_{3}, \mathrm{H}_{2} \mathrm{SO}_{4}$ and $\mathrm{H}_{3} \mathrm{PO}_{4}$. Results show that the percentage uptake values remain almost nearly constant at $95-99 \%$ at very low concentration up to about $0.01 \mathrm{M}$ then, decrease gradually at higher concentration up to $0.1 \mathrm{M}$. At concentration $0.1 \mathrm{M}$ and up, the percentage uptake decrease rapidly to reach nearly 15 to $3 \%$ at $1 \mathrm{M}$ concentration of $\mathrm{HCl}, \mathrm{H}_{3} \mathrm{PO}_{4}, \mathrm{HNO}_{3}$, and $\mathrm{H}_{2} \mathrm{SO}_{4}$,respectively.

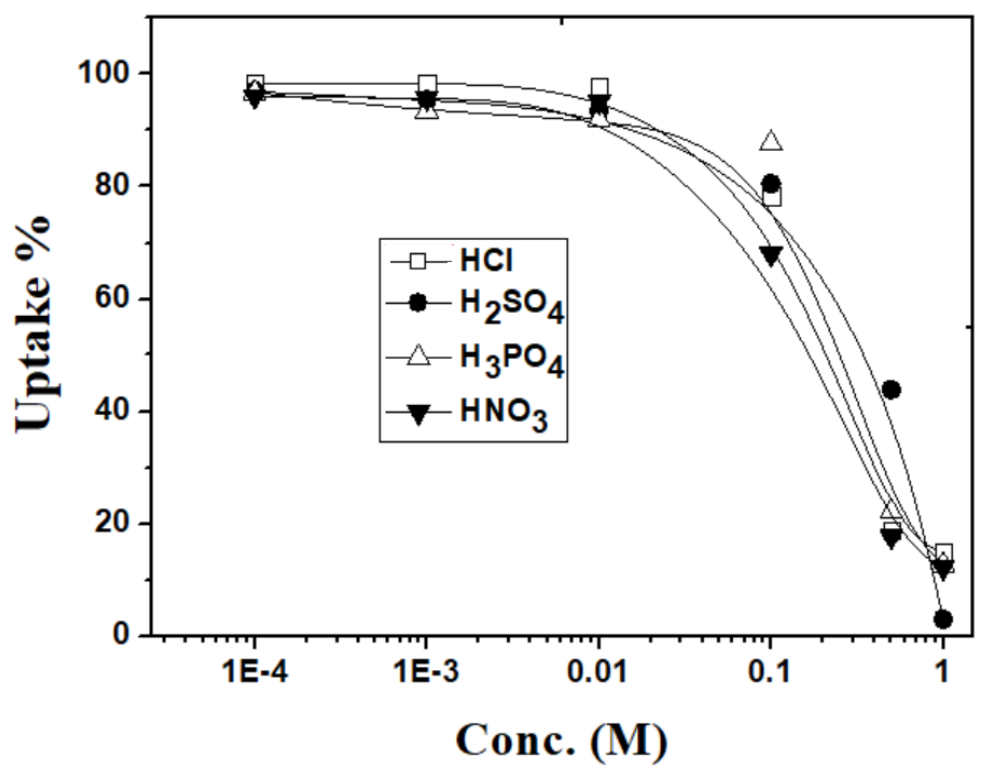

Fig. (2): Percentage uptake value of different concentrations of the inorganic acids $\mathrm{HCl}, \mathrm{HNO}_{3}$, $\mathrm{H}_{2} \mathrm{SO}_{4}$ and $\mathrm{H}_{3} \mathrm{PO}_{4}$ by GO $(160<\mathrm{P} . \mathrm{S}$. $<280 \mu \mathrm{m})$ at temp. $=25 \mathrm{C}^{\circ}$, contact time $=24.0 \mathrm{~h}$ and $\mathrm{V} /$ $\mathrm{m}=100\left(\mathrm{~mL} \cdot \mathrm{g}^{-1}\right)$.

b- Organic acids, acetic, oxalic, citric, tartaric and EDTA

Figure (3) shows the relationship between the percentage absorption of certain organic acids by GO and their concentration in solution. The investigated acids are acetic, oxalic, citric, tartaric and EDTA. The results indicated that all the acids are fully absorbed into GO from concentration 
solutions up to $0.01 \mathrm{M}$, then the percentage uptake decreases at concentrations higher than $0.01 \mathrm{M}$ as shown in this figure having the following sequence EDTA $<$ oxalic acid $<$ tartaric $=$ citric $<$ acetic acid.

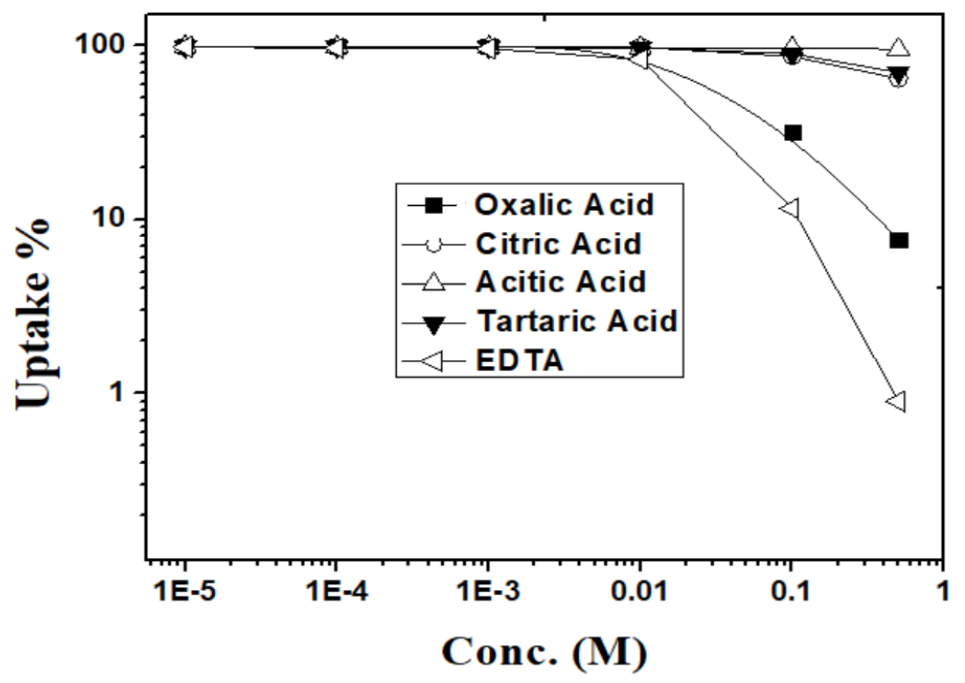

Fig. (3): Percentage uptake values at different concentrations of organic acids acetic, oxalic, citric, tartaric and EDTA by GO $(160<$ P.S. $<280 \mu \mathrm{m})$ at temp. $=25 \mathrm{C}^{\circ}$, contact time $=24.0 \mathrm{~h}$ and $\mathrm{V} / \mathrm{m}=100\left(\mathrm{~mL} \cdot \mathrm{g}^{-1}\right)$.

\section{2- Adsorption of Eu (III)}

a- Effect of pH: Figure (4) shows the impact of $\mathrm{pH}$ values (ranging from 1.0 - 5.5) on percentage uptake of $\mathrm{Eu}(\mathrm{III})$ on GO $(160<$ particle size $<280 \mu \mathrm{m})$ at $24 \mathrm{~h}$ contact time. It can be noticed that the percentage of the uptake increases when the $\mathrm{pH}$ value increases to about $\sim 4.5$ and then the uptake beings to gradually decrease. Eu(III) ion appears to hydrolyze at $\mathrm{pH}>5.6$, in the absence of complexing agents leading to slight decrease in the percentage uptake [18]. 


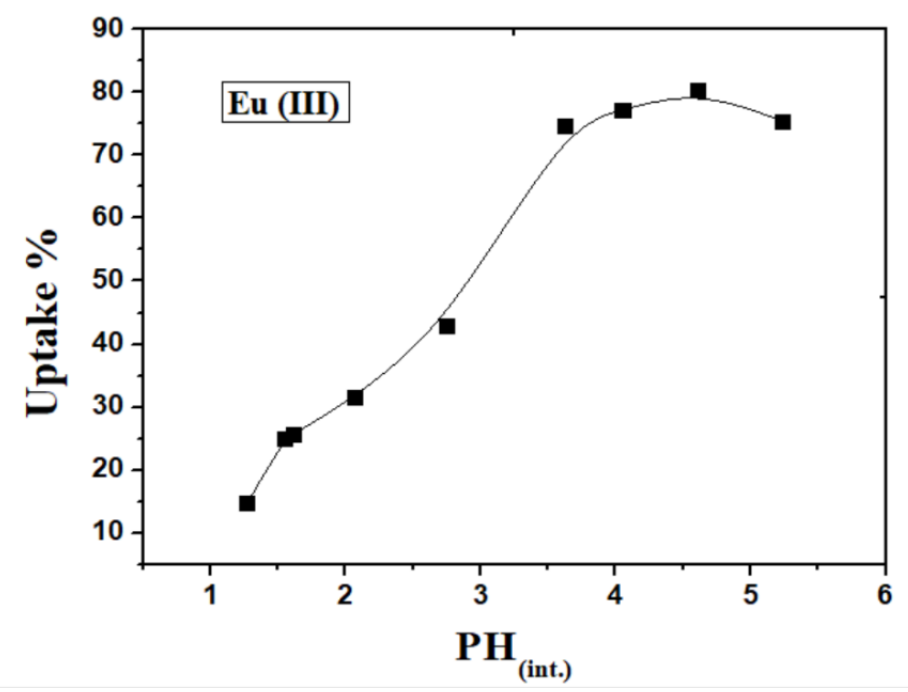

Fig. (4): $E$ ffect of $\mathrm{pH}_{\text {(int) }}$ on the percentage uptake of $\mathrm{Eu}(\mathrm{III})\left(5 \times 10^{-4} \mathrm{M}\right)$ on $\mathrm{GO}$ of Particle size $(160<$ p.s. $<280 \mu \mathrm{m})$ at temp. $=25^{\circ} \mathrm{C}$, contact time $=24.0 \mathrm{~h}$ and $\mathrm{V} / \mathrm{m}=100\left(\mathrm{~mL} . \mathrm{g}^{-1}\right)$.

The increase of the percentage uptake value with increasing $\mathrm{pH}$ may be attributed to deprotonating of the possible exchange sites (mainly - $\mathrm{COOH}$ groups) under the action of the multi-charged cations [19]. A proposed chemical structure of GO may be represented as follows:

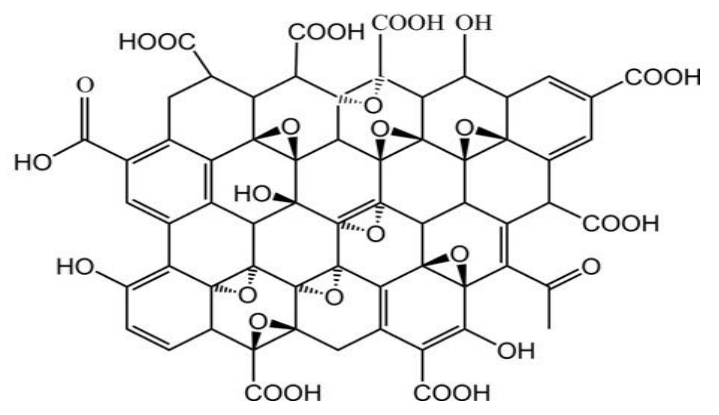

Fig. (5): Structure representation of GO. [20] and [21].

In addition, the high uptake values of the inorganic and organic acids at relatively low concentrations $\left(10^{-4}-10^{-2} \mathrm{M}\right)$ may indicate also anion exchange with $\mathrm{OH}^{-}$groups. Which means that GO may act as amphoteric sorbent.

b- Effect of particle size: The effect of particle size on Eu (III) adsorption on GO is reflected in Figure (6). As can be observed, the percentage absorption decreases with increased of particle size and equilibrium is reached after contact time $1500 \mathrm{~min}$. This may indicate that the sorption process 
rate is controlled by a diffusion either by a film or a particle diffusion [22].but not through chemically regulated one [23].

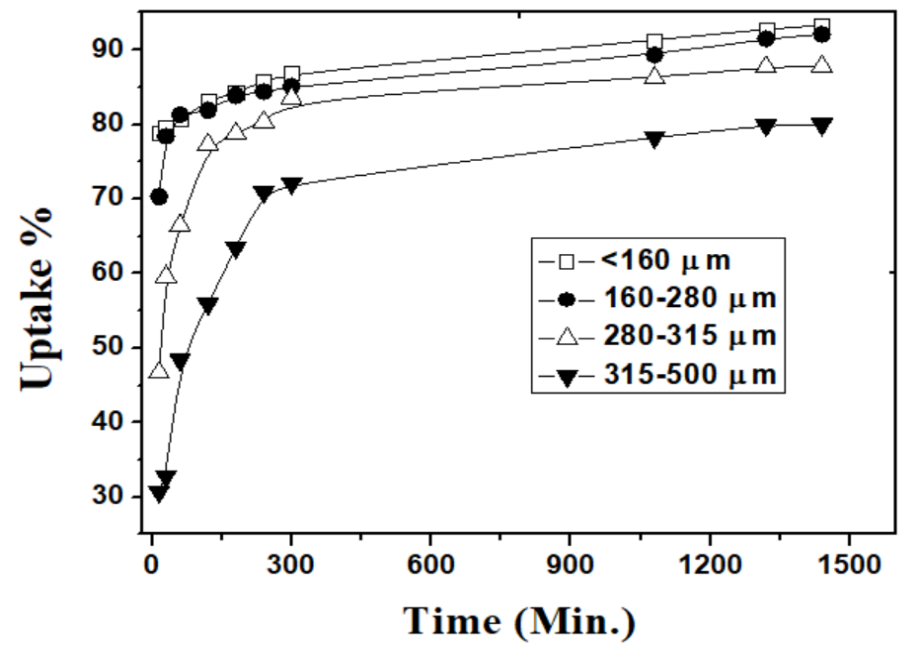

Fig. (6): Effect of contact time on the percentage uptake value of $\mathrm{Eu}$ (III) $5 \times 10^{-4} \mathrm{M}$ on GO at different particle size at Temp. $=35^{\circ} \mathrm{C}, \mathrm{pH}_{\text {(int) }}=4.5$ and $\mathrm{V} / \mathrm{m}=100\left(\mathrm{~mL} \cdot \mathrm{g}^{-1}\right)$.

The effect of diffusion was analyzed using the equation for particle diffusion $(5,6)$

$$
\begin{gathered}
\mathrm{F}=\mathrm{Q}_{\mathrm{t}} / \mathrm{Q}_{\mathrm{e}}=1-6 \pi^{-2} \sum_{n=1}^{\infty}\left[\exp \left(-n^{2} \pi^{2} D_{i} \mathrm{t} / \mathrm{r}^{2}\right) / \mathrm{n}^{2}\right] \\
\mathrm{Or} \\
\mathrm{F}=\mathrm{Q}_{\mathrm{t}} / \mathrm{Q}_{\mathrm{e}}=1-6 \pi^{-2} \sum_{n=1}^{\infty}\left[\exp \left(-n^{2} \beta \mathrm{t}\right) / \mathrm{n}^{2}\right] \\
\text { Where } \beta \mathrm{t}=\frac{\pi^{2} D_{i}}{r^{2}}
\end{gathered}
$$

$\mathrm{Q}_{\mathrm{t}}$ and $\mathrm{Q}_{\mathrm{e}}$ are respectively the quantities of the adsorbed ion at time $\mathrm{t}$ and at equilibrium, $\mathrm{r}$ is the radius of particle; and $\mathrm{D}_{\mathrm{i}}$ is the effective diffusion coefficient of the sorbate ion in the exchanger particle. The $\beta$ t values were determined using an equation derived by Reichenberg [24]; $\mathrm{D}_{\mathrm{i}}$ may be calculated from the slope $\beta \mathrm{t}$. $\beta \mathrm{t}$ is inversely proportional to the square of the particle radius. Since $F(r)$ is a function of the variable $D_{i} t / r^{2}$, the time required to attain any given degree of exchange is inversely proportional to the effective diffusion coefficient and is directly proportional to $\mathrm{r}^{2}$.

The relationship between $\beta \mathrm{t}$ and $\mathrm{t}$ for $\mathrm{Eu}$ (III) onto GO is shown in Figure (7). We found the plot of $\beta \mathrm{t}$ vs. $\mathrm{t}$ is a straight line not passing through the origin due to the percentage uptake reach about $50-70 \%$ at the first time. 


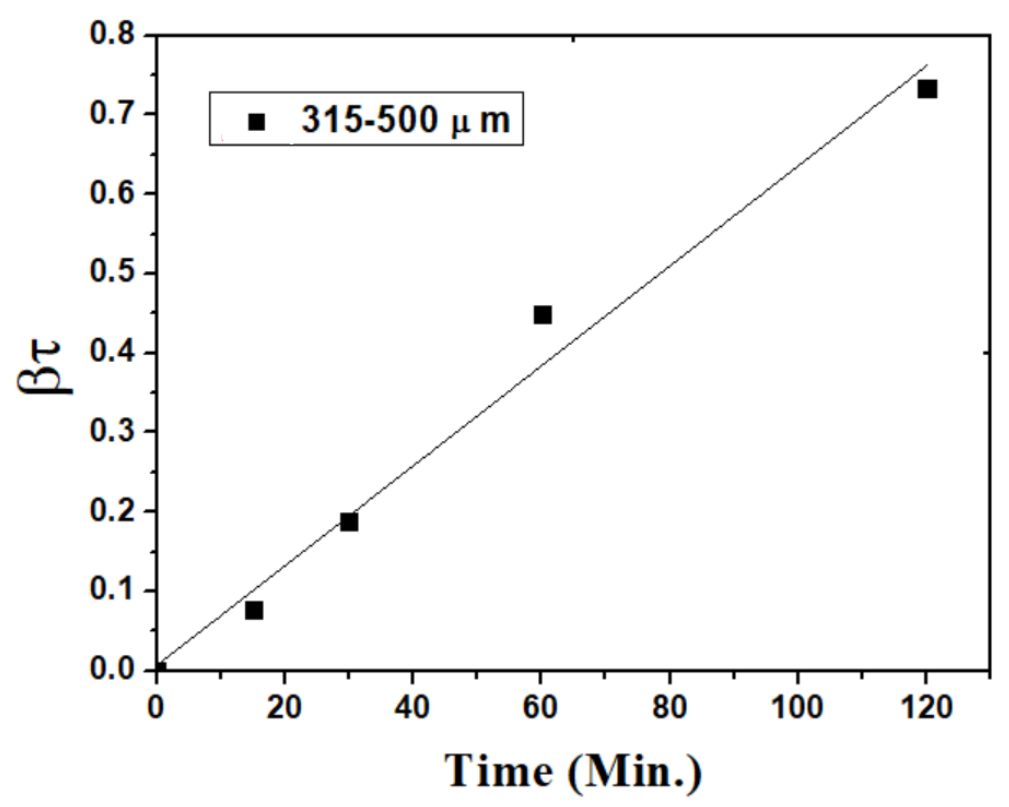

Fig. (7): Relationship between $\beta_{\mathrm{t}}$ and contact time for the sorption of $\mathrm{Eu}$ (III) on GO at $\mathrm{pH}$ init $=$ 4.5 , temp. $=35^{\circ} \mathrm{C}$ and $\mathrm{V} / \mathrm{m}=100\left(\mathrm{~mL} \cdot \mathrm{g}^{-1}\right)$.

From the above mentioned studies the, diffusion coefficients for the sorption of Eu (III) on GO is calculated in Table (1).

Table (1): Diffusion coefficients for adsorption of Eu (III) onto GO with at $35^{\circ} \mathrm{C}$.

\begin{tabular}{|c|c|c|c|}
\hline $\begin{array}{l}\text { particle } \\
\text { size }(\boldsymbol{\mu m})\end{array}$ & $\begin{array}{c}\text { Mean particle } \\
\text { radius, }(\mathbf{C m})\end{array}$ & $\mathbf{D}_{\mathbf{i}}\left(\mathbf{m}^{\mathbf{2}} \mathbf{.}^{\mathbf{- 1}}\right) \mathbf{\mathbf { x 1 0 } ^ { - \mathbf { 1 1 } }}$ & $\mathbf{R}^{\mathbf{2}}$ \\
\cline { 3 - 4 } & $\mathbf{E u}($ III) & Eu (III) \\
\hline $\mathbf{2 8 0 - 3 1 5}$ & 0.015 & 1.6719 & 0.9123 \\
\hline $\mathbf{3 1 5 - 5 0 0}$ & 0.0204 & 8.224 & 0.9824 \\
\hline
\end{tabular}

C-Effect of sorbate concentration: Effect of Eu (III) concentration on the percentage uptake on GO is shown in Figure (8). From this calculation it is noted that the percentage uptake decreases with the concentration rise. Which, assure that the sorption rate is controlled by a particle diffusion and not film diffusion [23]. 


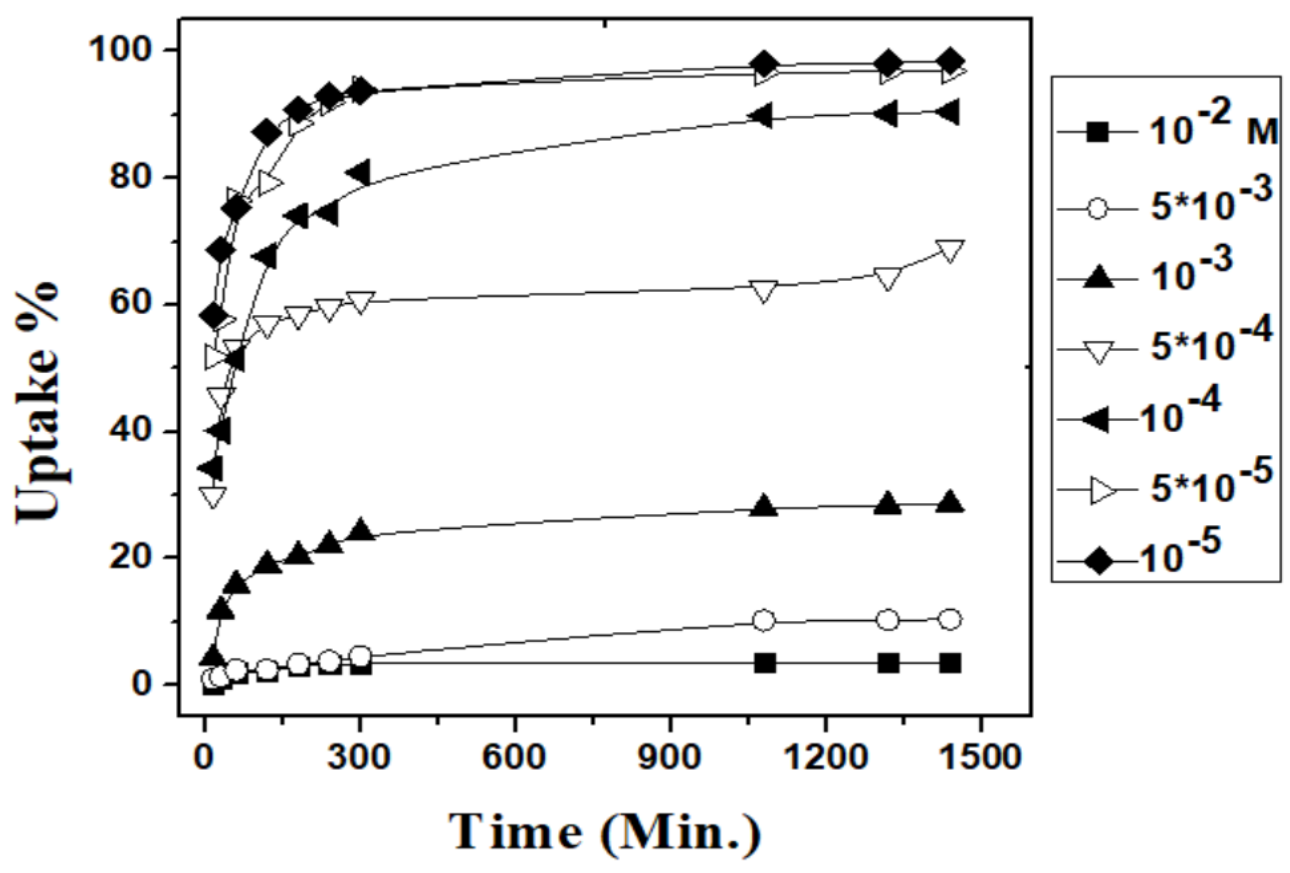

Fig. (8): Effect of $\mathrm{Eu}$ (III) concentration on the percentage uptake on $\mathrm{GO}(160<$ p.s. $<280 \mu \mathrm{m})$ at different contact time. Temp. $=35^{\circ} \mathrm{C}, \mathrm{pH}_{\text {(int) }}=3.52$ and $\mathrm{V} / \mathrm{m}=100\left(\mathrm{~mL} \cdot \mathrm{g}^{-1}\right)$.

d- Effect of temperature: Figure (9) reflects the impact of contact time at different temperatures at $25^{\circ} \mathrm{C}, 35^{\circ} \mathrm{C}$ and $45^{\circ} \mathrm{C}$ on the percentage uptake absorption of Eu (III) on GO. The increase of temperature from 25 to $45 \mathrm{C}^{\circ}$ has slight effect on the adsorption. The adsorbed fraction of the metal ions on $\mathrm{GO}$ is calculated using equations (7 and 8 ) at different temperature. 


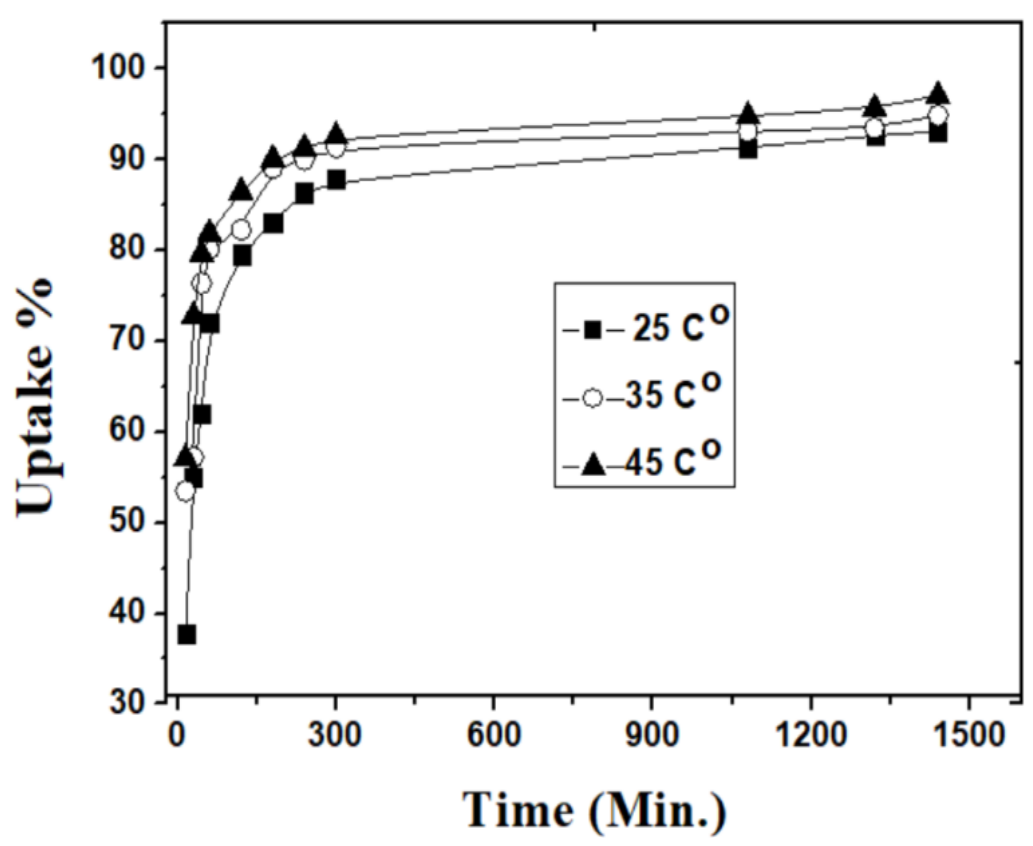

Fig. (9): Effect of contact time at different temperatures on the percentage uptake of Eu (III) on GO. Particle size $(160<$ p.s. $<280) \mu \mathrm{m}, \mathrm{pH}_{\text {int. }}=4.5, \mathrm{~V} / \mathrm{m}=\left(100 \mathrm{~mL}^{-1} \mathrm{~g}^{-1}\right)$, and $\mathrm{Eu}$ (III) concentration $=5 \times 10^{-4} \mathrm{M}$.

The free energy of the adsorption is giving by the Gibbs's equation from the analysis of the temperature effects on adsorption [19]:

$$
\Delta \mathrm{G}^{\circ}=-\mathrm{RT} \operatorname{Ln} \mathrm{K}_{\mathrm{c}}
$$

Where $\mathrm{K}_{\mathrm{c}}$ is adsorption equilibrium constant, $\mathrm{R}$ the gas constant, and $\mathrm{T}$ is the absolute temperature $(\mathrm{K})$. The sorption equilibrium constant $\left(\mathrm{K}_{\mathrm{c}}\right)$ is determined by using the following equation:

$$
\mathrm{K}_{\mathrm{c}}=\mathrm{F}_{\mathrm{e}} /\left(1-\mathrm{F}_{\mathrm{e}}\right)
$$

Where, $F_{e}$ is the metal ion fraction adsorbed at equilibrium. Beside the thermodynamic parameters $\Delta \mathrm{G}^{\mathrm{o}}, \Delta \mathrm{H}^{\mathrm{o}}$ and $\Delta \mathrm{S}^{\mathrm{o}}$, these values are determined from the slope and intercept of the plot of $\Delta \mathrm{G}^{\circ}$ versus $\mathrm{T}$ by using the following equation is appear in Figure (10):

$$
\Delta \mathrm{G}^{\circ}=\Delta \mathrm{H}^{\circ}-\mathrm{T} \Delta \mathrm{S}^{\circ}
$$




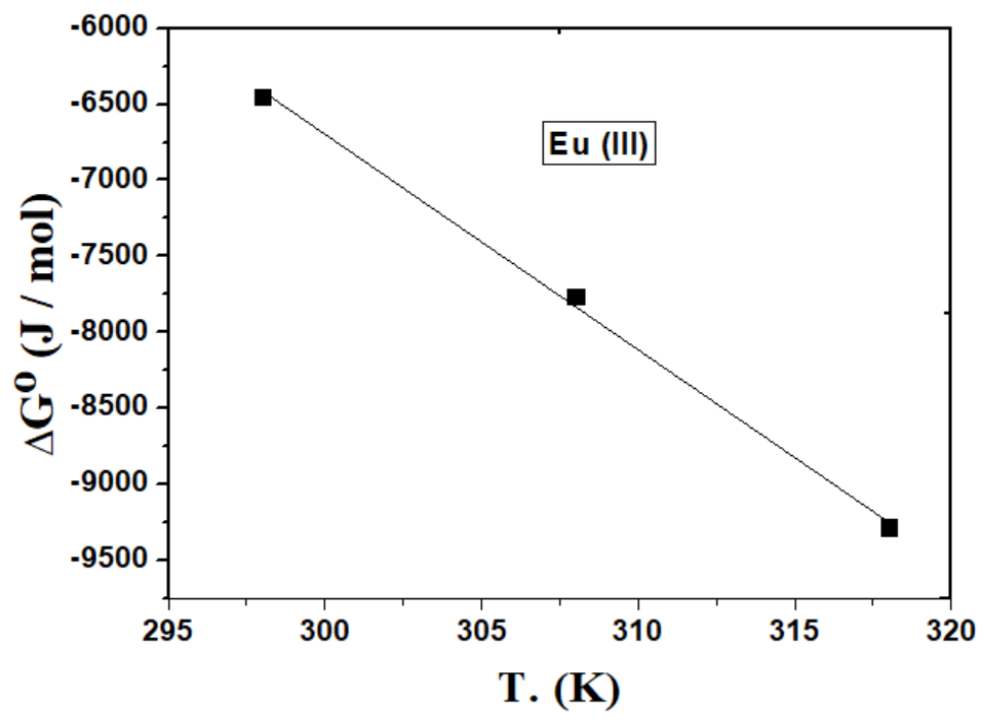

Fig. (10): Relationship between Gibbs free energy change and temperature of sorption of Eu (III) onto GO at Particle size $(160<$ p.s. $<280 \mu \mathrm{m})$.

The following Table (2) represents these data.

Table (2): Thermodynamic parameters for the adsorption of Eu (III), on GO at different temperatures.

\begin{tabular}{|c|c|c|c|c|}
\hline $\mathbf{T}(\mathbf{K})$ & $\mathrm{Kc}=\mathrm{Fe} /(1-\mathbf{F e})$ & $\Delta \mathbf{G}^{\circ}(\mathbf{k J} / \mathbf{m o l})$ & $\Delta \mathbf{H}^{\circ}(\mathbf{k J} / \mathbf{m o l})$ & $\Delta \mathbf{S}^{\circ}(\mathbf{k J} / \mathbf{m o l})$ \\
\hline & Eu (III) & Eu (III) & Eu (III) & Eu (III) \\
\hline 298 & 13.49275 & -6.218 & 35.77 & 0.1415 \\
\hline 308 & 20.73913 & -7.598 & & \\
\hline 318 & 33.48276 & -9.008 & & \\
\hline
\end{tabular}

Adsorption of rising temperatures ensures that adsorbent interactions are enhanced by the temperature. The ions have also been dehydrated greatly, leading to smaller sizes and higher $\mathrm{K}_{\mathrm{c}}$ values at higher temperature. The negative values of $\Delta \mathrm{G}^{\circ}$ confirm the process feasibility and the spontaneous nature of the sorption process.

Adsorption isotherms: Two commonly used isotherm models, Langmuir, and Freundlich are being applied in this study to analyze Eu (III) sorption equilibrium data on the GO. The linear form of Langmuir isotherm is given by the equation [25] and [26] below: 


$$
\frac{\mathrm{C}_{\mathrm{e}}}{\mathrm{q}_{\mathrm{e}}}=\frac{1}{\mathrm{~K}_{\mathrm{L}} \mathrm{q}_{\max }}+\frac{\mathrm{C}_{\mathrm{e}}}{\mathrm{q}_{\max }}
$$

Where, in the solution, $\mathrm{C}_{\mathrm{e}}(\mathrm{mg} / \mathrm{L})$ is the equilibrium concentration of adsorbate, $\mathrm{qe}_{\mathrm{e}}\left(\mathrm{mg} \cdot \mathrm{g}^{-1}\right)$ is a unit of adsorbed adsorbent, $\mathrm{q}_{\max }\left(\mathrm{mg} \cdot \mathrm{g}^{-1}\right)$ consists of the theoretical maximum sorption capacity and $\mathrm{K}_{\mathrm{L}}\left(\mathrm{L} \cdot \mathrm{mg}^{-1}\right)$ is the energy related adsorption of langmuir sorption constant. $\mathrm{q}_{\max }$ and $\mathrm{K}_{\mathrm{L}}$ are calculated from the slope and intercept of linear plots of $\frac{C_{e}}{q_{e}}$ against $\mathrm{C}_{\mathrm{e}}$ Fig.(11). Separation factor $\left(\mathrm{R}_{\mathrm{L}}\right)$ calculated from the following equation: [25].

$$
R_{L}=\frac{1}{1+K_{L} C o}
$$

Where, Co consists of adsorbate initial concentration (mg. $\left.\mathrm{L}^{-1}\right)$.

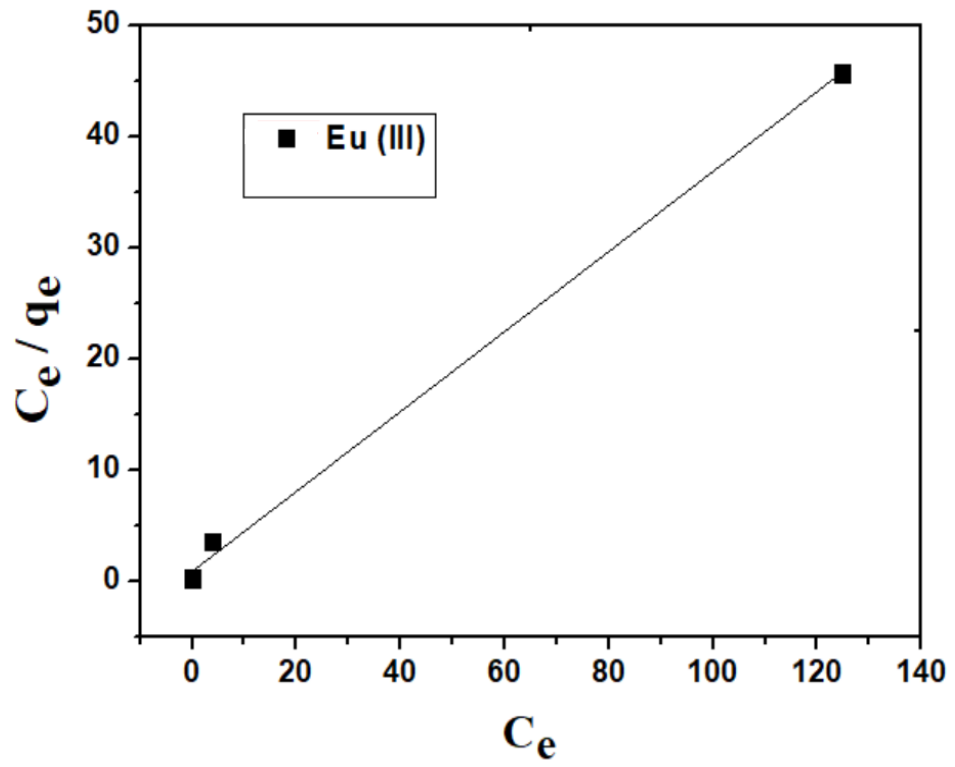

Fig.(11): Langmuir adsorption isotherm for Eu (III) on GO. $(160<$ p.s. $<280) \mu \mathrm{m}$, contact time $=24 \mathrm{~h}, \mathrm{pH}_{\text {init }}=4.9 \pm 0.05$, temp. $=35 \pm 1{ }^{\circ} \mathrm{C}$ and $\mathrm{V} / \mathrm{m}=100\left(\mathrm{~mL} \cdot \mathrm{g}^{-1}\right)$.

The logarithmic form of Freundlich isotherm model can be expressed as follow [27]:

$$
\log q_{\mathrm{e}}=\log k_{f}+\frac{1}{\mathrm{n}} \log C e
$$

Where, $\mathrm{C}_{\mathrm{e}}\left(\mathrm{mg} \cdot \mathrm{L}^{-1}\right)$ is a unit of the equilibrium concentration of adsorbate in the solution, $\mathrm{q}_{\mathrm{e}}$ (mg. $\mathrm{g}^{-1}$ ) consists of the amount of adsorbate adsorbed per unit mass of adsorbent, $\mathrm{K}_{\mathrm{f}}$ and $\mathrm{n}$ are Freundlich constants, $\mathrm{K}_{\mathrm{F}}$ is an adsorption capacity of adsorbent and $\mathrm{n}$ is an indicator of favorable or unfavorable process of adsorption. $\mathrm{K}_{\mathrm{F}}$ and $\mathrm{n}$ are the Freundlich constants and are determined 
from the intercept and slope of the relation between $\log q_{e}$ against $\log C_{e}$. these data are shown in Figure (12).

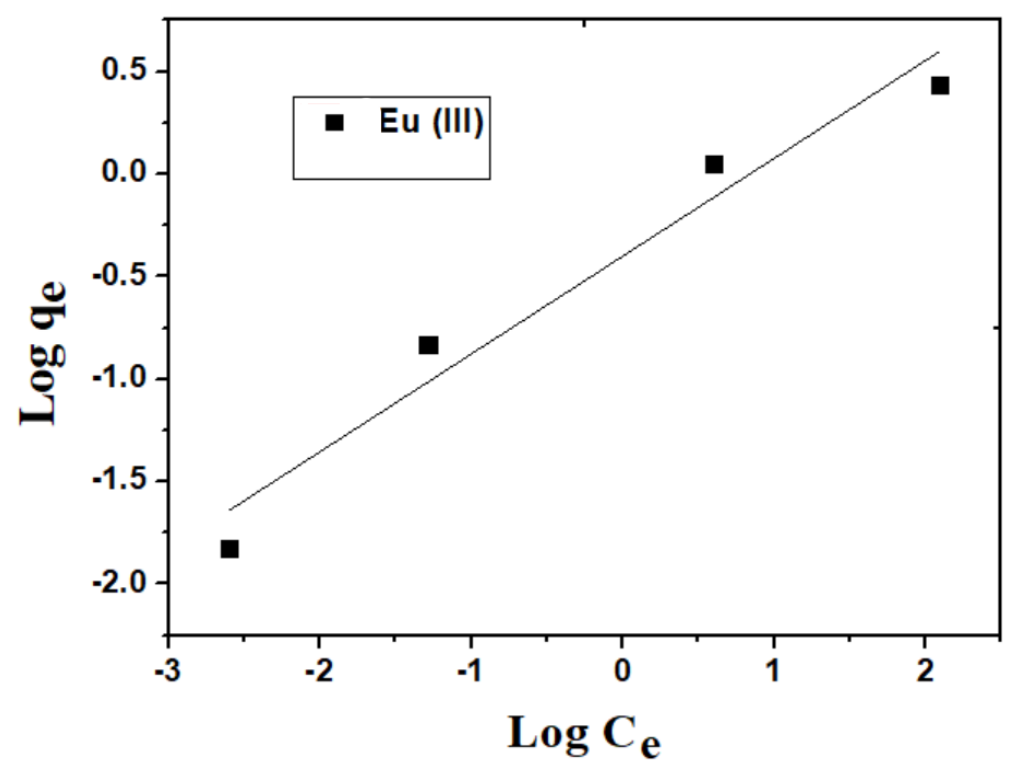

Fig.(12): Freundlich adsorption isotherm for $\mathrm{Eu}(\mathrm{III})$ on GO. $(160<$ p.s. $<280) \mu \mathrm{m}$, contact time $=24 \mathrm{~h}, \mathrm{pH}_{\text {init }}=4.9 \pm 0.05$, temp. $=35 \pm 1^{\circ} \mathrm{C}$ and $\mathrm{V} / \mathrm{m}=\left(100 \mathrm{~mL} \cdot \mathrm{g}^{-1}\right)$.

The $\mathrm{n}$ value means that the process is adsorbed favorability. The high correlation coefficient $\left(\mathrm{R}^{2}\right)$ values given in Table (3) indicate that the experimental data for the Eu (III) adsorption follow Langmuir model better than Freundlich model.

Table (3): Langmuir and Freundlich isotherm parameters for the adsorption of Eu (III) on GO.

\begin{tabular}{|c|c|c|c|c|c|c|c|}
\hline & \multicolumn{3}{|c|}{ Langmuir model } & \multicolumn{3}{c|}{ Freundlich model } \\
\hline & qmax $_{\text {mag/g) }}$ & K & RL & $\mathbf{R}^{\mathbf{2}}$ & $\mathbf{K}_{\mathbf{f}}$ & $\mathbf{1 / n}$ & $\mathbf{R}^{\mathbf{2}}$ \\
\hline Eu(III) & 2.78 & 0.419 & $0.015-0.94$ & 0.997 & 0.397 & 0.477 & 0.49 \\
\hline
\end{tabular}

Adsorption kinetics: Pseudo-first-order is used for adsorption kinetics behavior of Eu (III) on GO from the liquid phase and is given by the following equation: [24].

$$
\ln \left(q_{e}-q_{t}\right)=\ln q_{e}-K_{1} t
$$


where $\mathrm{q}_{\mathrm{e}}$ is metal ion adsorbing onto adsorbent at equilibrium, $\mathrm{q}_{\mathrm{t}}$ consists of metal ion adsorbed at times, $\mathrm{t}$ is the time of adsorption duration and $\mathrm{k}_{1}$ is the rate constant of the equation. This data is shown in Figure (13).

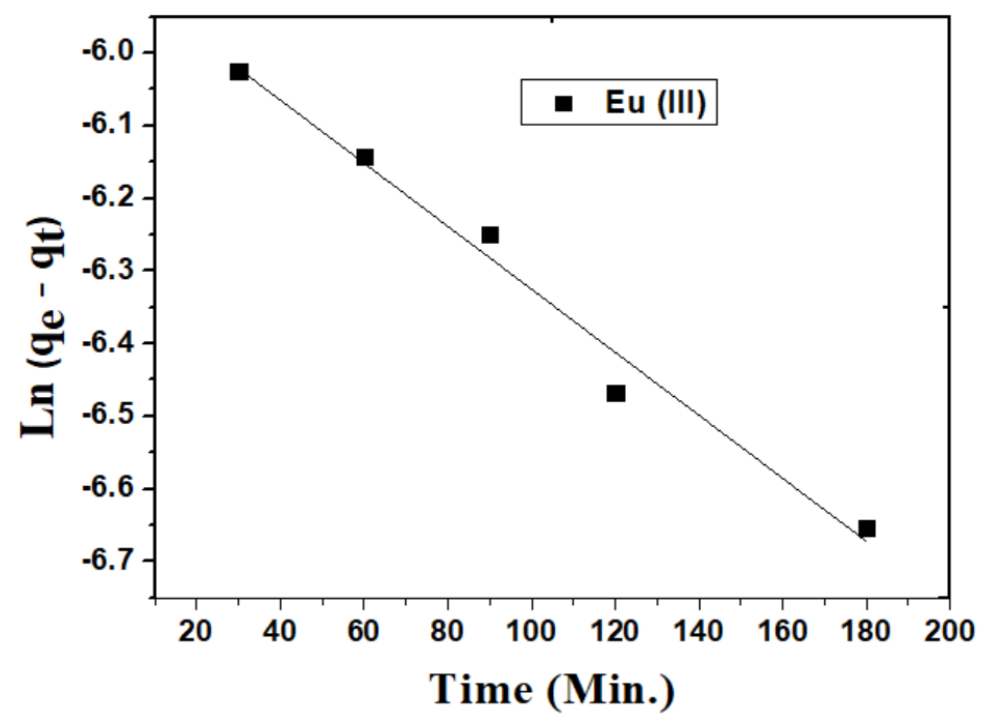

Fig. (13): Pseudo first-order kinetic plots for the sorption of Eu (III) from aqueous solutions onto GO $(160<$ p.s. $<280 \mu \mathrm{m})$ at temp. $=35^{\circ} \mathrm{C}, \mathrm{pH}_{(\mathrm{int})}=4.91$ and $\mathrm{V} / \mathrm{m}=100\left(\mathrm{~mL} \cdot \mathrm{g}^{-1}\right)$.

The following linear equation can be used to describe the pseudo-second-order model [24].

$$
\frac{t}{q_{t}}=\frac{1}{K_{2} q_{e}^{2}}+\frac{1}{q_{e}} t
$$

Where, $\mathrm{K}_{2}$ is constant of adsorption rate in pseudo-second-order $\left(\mathrm{g} \cdot \mathrm{mg}^{-1} \cdot \mathrm{min}^{-1}\right)$. The slope and intercept of the plots of $t / q_{t}$ against $t$ is calculated for $q_{e}$ and $K_{2}$ values. Figure (14) displays the data collected. 


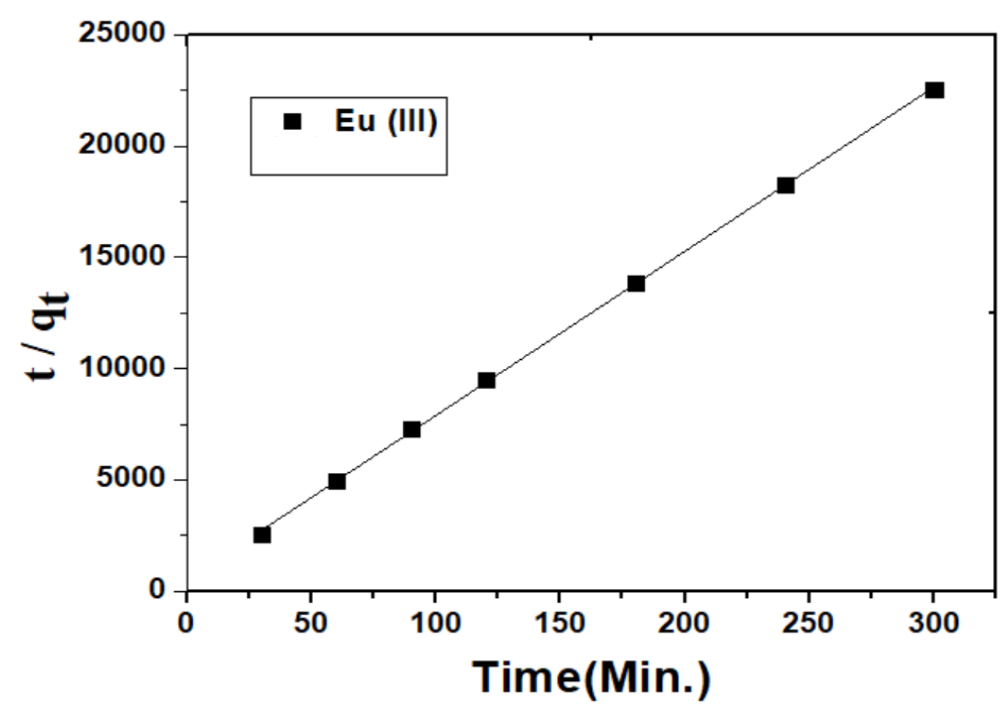

Fig. (14): Pseudo second-order kinetic plots for the sorption of Eu(III) from aqueous solutions onto GO $(160<$ p.s. $<280 \mu \mathrm{m})$ at temp. $=35^{\circ} \mathrm{C}, \mathrm{pH}_{\text {(int) }}=4.91$ and $\mathrm{V} / \mathrm{m}=100\left(\mathrm{~mL} . \mathrm{g}^{-1}\right)$.

The pseudo-second order kinetic is found to fit sorption data better than the pseudo-first-order model as shown in Table (4). The correlation coefficients $\left(\mathrm{R}^{2}\right)$ are over 0.99 .

Table (4): Adsorption kinetics parameters for the adsorption of Eu (III) from aqueous solutions on GO.

\begin{tabular}{|l|l|l|l|l|l|l|}
\hline parameters & \multicolumn{4}{|c|}{ Pseudo- first -order } & \multicolumn{3}{l|}{ Pseudo- second -order } \\
\hline Ions & $\mathrm{K}_{1}\left(\mathrm{~min}^{-1}\right)$ & $\mathrm{q}_{\mathrm{e}}\left(\mathrm{mg} \cdot \mathrm{g}^{-1)}\right.$ & $\mathrm{R}^{2}$ & $\mathrm{~K}_{2}\left(\mathrm{~g} \cdot \mathrm{mg}^{-1} \cdot \mathrm{min}^{-1}\right)$ & $\mathrm{q}_{\mathrm{e}}\left(\mathrm{mg} \cdot \mathrm{g}^{-1)}\right.$ & $\mathrm{R}^{2}$ \\
\hline Eu(III) & 0.00434 & 0.0028 & 0.976 & $0.1049 \times 10^{-5}$ & 13.55 & 0.9996 \\
\hline
\end{tabular}

It can be concluded from this study that GO is a good sorbent for the removal and separation of $\mathrm{Eu}$ (III).

\section{CONCLUSION}

Graphene oxide samples are synthesized and characterized with FT-IR, XRD and SEM, respectively. These samples are used for the adsorption of ${ }^{152+154} \mathrm{Eu}$ (III) under specific conditions, of certain inorganic and organic acids. From the data obtained in this analysis, a highly efficient for the adsorption of acetic, oxalic, citric, tartaric and EDTA organic acids as well as of $\mathrm{HCl}, \mathrm{HNO}_{3}$, $\mathrm{H}_{2} \mathrm{SO}_{4}$ and $\mathrm{H}_{3} \mathrm{PO}_{4}$ inorganic acids from dilute solutions at low concentrations $\left(10^{-4}-10^{-2} \mathrm{M}\right)$ on GO. At the same time, the ionic species being studied is strongly adsorbed on GO. It is possible to infer 
that $\mathrm{GO}$ could be used as an anion exchanger with $\mathrm{OH}^{-}$groups and a cation exchanger with carboxyl $-\mathrm{COOH}$ groups. This is to say, GO has amphoteric character.

The data obtained also demonstrated that in all case the adsorption is controlled by particle diffusion. The diffusion coefficients are determined from the values of the studied ions within the range of $10^{-11} \mathrm{~m}^{2} \cdot \mathrm{s}^{-1}$ which indicating that the sorption has a chemisorption in nature. From studying the effect of temperature the thermodynamic parameters $\Delta \mathrm{G}^{\circ}, \Delta \mathrm{H}^{\circ}$ and $\Delta \mathrm{S}^{\circ}$ of the sorption reaction were calculated. The adsorption in the case of Eu (III) is considered to following Langmuir isotherm and the adsorption follows a pseudo second order model in the cationic species.

\section{REFERENCE}

[1] A. Waseem, H. Ullah, M.K. Rauf and I. Ahmad, "Distribution of natural uranium in surface and groundwater resources.", a review, Crit. Rev. Environ. Sci. Technol. 45 : (2015) 2391-2423.

[2] Y. Sun, S. Yang, Y. Chen, C. Ding, W. Cheng and X. Wang, "Adsorption and desorption of U (VI) on functionalized graphene oxides: a combined experimental and theoretical study", Environ. sci. \& technol., 49 : (2015) 4255-4262.

[3] K. Buesseler, M. Aoyama, and M. Fukasawa, "Impacts of the Fukushima Nuclear Power Plants on Marine Radioactivity", Environ. Sci. Technol. 45 : (2011) 9931-9935.

[4] S. Stankovich, D. A. Dikin, G. H. B. Dommett, K. M. Kohlhaas, E. J. Zimney, E. A. Stach, R. D. Piner, S. T. Nguyen, R. S. Ruoff, "Graphene-Based Composite Materials.", Nature, 442 : (2006) 282-286.

[5] Y. Xie, E. Helvenston, N.L. Shuller, and B. Powell, "Surface complexation modeling of Eu(III) and U(VI) interactions with graphene oxid.", Environ. Sci. Technol. 50 : (2016) 1821-1827.

[6] W. Hung, Q. An, M. Guzman, H. Lin, S. Huang, W. Liu, C. Hu, K. Lee and J. Lai, "Pressureassisted self-assembly technique for fabricating composite membranes consisting of highly ordered selective laminate layers of amphiphilic graphene oxide", Carbon N. Y., 68 : (2014) 670 -677 .

[7] W. Hung, J.X. Li, X.M. Ren, C.L. Chen and X.K. Wang,"Few-layered graphene oxide nanosheets as superior sorbents for heavy metal ion pollution management", Environ. Sci. Technol., 45: (2011) 10454 - 10462.

[8] J. D. Begg, M. Zavarin, P.Zhao, S. J. Tumey, B. Powell, and A. B. Kersting, " Pu (V) and Pu (IV) sorption to montmorillonite", Environ. Sci. \& technol. 47 : (2013) 5146 - 5153.

[9] N. Pan, D. Guan, T. He, R. Wang, I. Wyman, Y. Jin, and C. Xia, "Removal of Th${ }^{4+}$ ions from aqueous solutions by graphene oxide", J. Radioanal. Nucl. Chem., 298 : (2013) 1999 - 2008.

[10] W.S. Hummers, and R.E. J. Offeman, Am. Chem. Soc. 80 : (1958) 1335. 
[11] G. Zhao, L. Jiang, Y. He, J. Li, H. Dong, X. Wang, and W. Hu, "Sulfonated graphene for persistent aromatic pollutant management",Adv. Mater. 23 : (2011) 3959 - 3963.

[12] W. Xiangxue, F. Qiaohui, Y. Shujun, and C. Zhongshan, "High sorption of U (VI) on graphene oxides studied by batch experimental and theoretical calculations", Chem. Eng. J., 287 : (2016) $448-455$.

[13] L. Shahhriary, and A. A. Athawale,"Graphene Oxide Synthesized by using Modified Hummers Approach", Int. J. Renew. Energy Environ. Eng., 02 : (2014) 58 - 63.

[14] D.C. Marcano, D.V. Kosynkin, J.M. Berlin, A. Sinitskii, Z. Sun, A. Slesarev, L.B. Alemany, W. Lu, and J.M. Tour, "Improved Synthesis of Graphene Oxide", ACS Nano 4:(2010) 4806 -4814.

[15] D. Chen, H. Feng, and J. Li, "Graphene oxide: preparation, functionalization, and electrochemical applications", Chem. Rev. 112 : (2012) 6027 - 6053.

[16] M.D. Stoller, S. Park, Y. Zhu, J. An, and R.S. Ruoff, "Graphene based Ultracapacitors", Nano Lett., 8 : (2008) $3498-3502$.

[17] C. Li, and G. Shi,"Three-dimensional graphene architectures.Nanoscale",18 : (2012) 5549 63.

[18] G.K. Schweitzer, and L.L. Pesterfield, "The aqueous chemistry of the elements", Oxford University Press, New York, U.S.A. (2010) 262 - 274.

[19] F.H. El-sweify, A. A. Abdel-fattah, M. A. Ghamry, S. M. Aly, and M.F. El-shahat, "Adsorption of ${ }^{141} \mathrm{Ce}(\mathrm{III}),{ }^{160} \mathrm{~Tb}(\mathrm{III})$ and ${ }^{169} \mathrm{Yb}$ (III) on the synthesized inorganic ion exchanger, zirconium titanium phosphate", Radio. Chem. 62 : (2020) 335-346.

[20] P. Tan, J. Sun, Y. Hu, Z. Fang, Q. Bi, Y. Chen, and J. Cheng, J. Hazard. Mater. 1 : (2015) $297-251$.

[21] W. Peng, H. Li, Y. Liu, and S. Song, J. Mol. Liq. 65 : (2016) $221-82$.

[22] A. Clearfield, "Inorganic Ion Exchange Materials", (1982) CRC Press, Boca Raton Fl.

[23] D. Reichenberg, "Selectivity of ion exchange", J.A. Marinsky, and Y. Marcus, Marcel Deker (Eds). "A series of Advances", Inc., New York, 1 : (1965) 227.

[24] D. Reichenberg, J. Am. Chem. Soc., 75 : (1953) 589.

[25] K.Y. Foo, and B.H. Hameed, "Insights into the modeling of adsorption isotherm systems", Review., Chem. Eng. J., 156 : (2010) 2 - 10.

[26] I. M. Abdelmonem, E. Metwally, T. E. Siyam, F. Abou El-Nour, and A.M. Mousa, "Radiation synthesis of starch-acrylic acid-vinyl sulfonic acid/ multiwalled carbon nanotubes composite for the removal of ${ }^{134} \mathrm{Cs}$ and ${ }^{152+154} \mathrm{Eu}$ from aqueous solutions", J. Radioanal. Nucl. Chem. (2019), https://doi.org/10.1007/s10967-018-6392-1. 
[27] A. M. Emara, F.H. El-sweify, Sh. F. Abo-zahra, and A. I. Hashim, "Removel of Cs-137 and Sr-90 from reactor actual liquid wast samples using anew synthesized bionanocomposite-based carboxymethylcellulose", Radiochimica Acta, :(2019)107. 


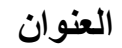

دراسات حول سلوك ادمصاص (G4,152Eu(III على أكسيد الجرافين المحضر (GO)

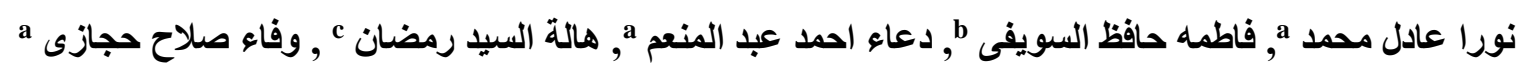

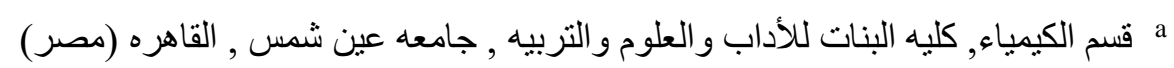

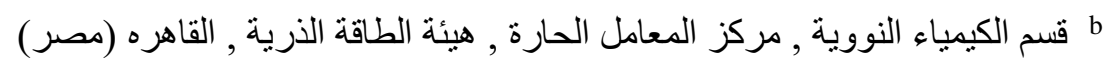

c قسم النظائرو المولدات المشعه , مركز المعامل الحارة , هيئة الطاقة الذرية , القاهره (مصر ) هرهز

\section{الملخص}

154,152Eu تمضير عينات من أكسيد الجر افين (GO) محلياً لإستخدامه في إدمصاص الأجز اء النووية (النويدات)

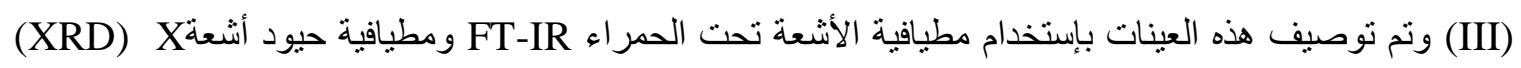
وتقنية المسح المجهري الإلكتروني (SEM). هذه العينات استخدمت لدر اسه إدمصاص بعض الاحماض غير العضويه

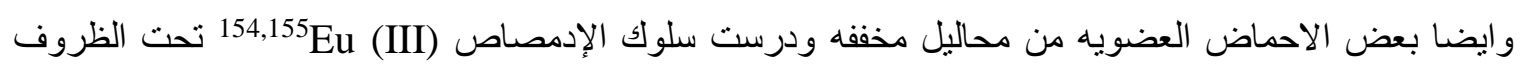
الإستاتيكية. ودراسة تأثير كل من الأس الهيدروجيني للمحاليل pH وزمن التلامس وحجم الجسيمات للمادة الصلبة وتركيز الأيونات في المحاليل ودرجة الحرارة علي حركية الإدمصاص وأيضا دراسة العوامل الديناميكية الحر ارية مثل التغيير في , وتحليل أيزونزرومات حركية عمليات الإدمصاص بإستخدام نماذج (models مختلفة. وقد وجد أن الإدمصاص في حالة Eu يتبع أيزوثيرم لانجيمير أفضل منه في حالة أيزوثيرم فروندليش ـ كما وجد أن الإدمصاص يتبع الحركية من الدرجة الثانية. 